\title{
Quality characteristics of Nabak kimchi with freeze-dried ingredients during storage
}

\author{
Seon-Hwa Cheon, Mi-Ran Kang, Hye-Young Seo* \\ Research and Development Division Industrial Technology Research Group, World Institute of Kimchi, Gwangju 61755, Korea
}

\section{동결건조한 원부재료를 이용하여 제조한 나박김치의 저장 중 품질 특성}

\author{
천선화·강미란·서혜영* \\ 세계김치연구소
}

\begin{abstract}
This study investigated the possibility of usage of freeze-dried ingredients for the preparation of Nabak kimchi. The quality characteristics of Nabak kimchi using freeze-dried ingredients (radish, kimchi cabbage, green onion, garlic and ginger) were monitored during storage at $4^{\circ} \mathrm{C}$. The initial $\mathrm{pH}$ of Nabak kimchi was 5.76 5.93, however, it decreased significantly over increasing storage periods $(\mathbf{p}<0.05)$. The titratable acidity of Nabak kimchi increased during storage, reaching $0.43 \sim 1.08 \%$. Among the freeze-dried samples, those treated with freeze-dried radish and minor ingredients showed lower titratable acidity than that of the control. The initial number of total aerobic and lactic acid bacteria were 5.57 6.25, and 5.52 6.24 $\log$ CFU/g, respectively. After 28 days, the population of total aerobic and lactic acid bacteria in the raw ingredients and freeze-dried minor ingredients was less than $8.0 \log$ CFU/g, but more than $9.0 \mathrm{log}$ CFU/g in other samples. Yeasts and molds in Nabak kimchi were detected up to 2 3 $\log \mathrm{CFU} / \mathrm{g}$, but coliforms were not detected in all samples during storage. The score of firmness and overall acceptability in the control, raw ingredients and freeze-dried minor ingredients were significantly higher than others $(\mathbf{p}<\mathbf{0 . 0 5})$. These results indicated that freeze-dried ingredients, such as green onion, garlic, and ginger, can be used in kimchi and would delay microbial growth and extend the shelf-life of kimchi without any deduction of sensory quality.
\end{abstract}

Key words : Nabak kimchi, freeze drying, Kimchi cabbage, radish, quality characteristics

\section{서 론}

김치는 배추 또는 무 등을 소금에 절인 후 각종 채소류 특히, 고추, 마늘, 파 등의 부재료를 첨가하여 적절하게 발효 숙성시킨 우리나라의 전통 채소발효식품으로 첨가되는 재 료에 따라 다양하게 구분된다(1). 그 중 무김치는 조선시대 에 들어와서 나박김치, 동치미, 총각김치, 무청김치 등의 형태로 등장하는데 무김치에서도 국물을 주로 섭취하는

*Corresponding author. E-mail : hyseo@wikim.re.kr Phone : 82-62-610-1731, Fax : 82-62-610-1850

Received 29 October 2015; Revised 21 January 2016; Accepted 12 February 2016.

Copyright (c) The Korean Society of Food Preservation. All rights reserved.
물김치로는 동치미, 열무김치, 나박김치 등이 있다 $(2,3)$. 이 는 일반적인 김치 재료와 동일하게 배추, 무, 파, 고추, 생강, 마늘, 찹쌀풀 등과 같은 다양한 부재료를 소금물에 첨가하 여 발효시켜 제조하며, 염도 1 2\%에서 Lactobacillus, Leuconostoc, Streptococcus 등의 다양한 젖산균에 의해 생 성된 젖산과 이산화탄소가 짠맛과 부재료의 조직감과 어울 려 독특한 맛과 향미가 부여되는 것이 특징이다. 그러나 물김치는 제조 시 사용되는 물의 양이 많기 때문에 첨가되 는 재료의 조직 연화가 빠르고, 용출된 영양성분에 의해 발효가 신속하게 진행되는 단점이 있다(4-6).

나박김치는 겨울에 가장 많이 섭취하는 동치미와 달리 동치미가 없는 계절의 대표적인 물김치로서 젓갈류 같은 동물성 재료를 사용하지 않고 무를 주재료로 하고 마늘, 생강과 소금을 기본재료로 사용하여 맛이 담백한 것이 특징 
이다. 그러나 나박김치를 포함한 다양한 김치는 김치의 재 료나 양념의 종류, 발효 온도 및 미생물에 따라 발효가 다르 게 일어나지만 저장 기간 중 조직의 연화현상 및 산 생성으 로 인해 보존기간이 짧아 상품으로서의 가치가 떨어지는 것으로 알려져 지금까지 김치의 저장기간을 연장시키고자 하는 연구가 꾸준히 진행되고 있다(7-10).

동결건조는 삼중점 이하의 온도와 압력 하에 동결된 물 질내의 수분을 제거하는 방법으로 식품 등의 원료를 동결상 태에서 승화와 탈습에 의해 물이나 용매류를 증기로 바뀌게 하여 동결상태에서 건조가 이루어지므로 건조물의 열변성 이 적고, 향기성분의 손실이 적으며, 다공성 구조가 잘 보존 되는 것으로 알려져 있다(11-13). 이러한 동결건조는 다른 건조방법에 비하여 건조된 시료의 품질과 복원성이 우수하 고 고온의 가열과정 없이 건조되어 열에 의해 파괴될 수 있는 성분의 손실을 최소화할 수 있다는 특징이 있으므로 김치의 품질 변화를 최소화하면서 저장성을 연장시킬 수 있는 방법으로 고려될 수 있다(14-17).

현재까지 진행된 동결건조 김치에 대한 연구로는 동결건 조 김치(18) 및 동결건조 열무김치의 품질특성(19)에 대한 연구, 동결건조 시간이 동결건조 김치의 품질에 미치는 영 향(20), 동결건조에 의한 김치의 휘발성 냄새성분(21)에 대 한 연구 등 제조된 김치를 동결건조하여 품질특성 변화를 살펴본 연구는 많이 진행되었으나, 동결건조한 원부재료를 이용하여 김치를 제조한 연구는 이루어지지 않은 실정이 다. 또한 김치 제조 시 첨가되는 다량의 물로 인해 발효가 빠르게 진행되는 특성을 가진 물김치에 대한 연구도 제조표 준화(22) 및 발효조건(23)에 대한 연구와 저장성 연장을 위해 천연추출물인 모과추출물(24), 클로렐라분말(25), 오 미자추출물(26) 등을 첨가한 연구만 진행되었을 뿐 물리적 처리방법에 의해 저장성 연장에 대한 연구는 미흡한 실정이다.

따라서 본 연구에서는 숙성이 빠르고 제조방법이 단순한 나박김치에 동결건조한 원부재료를 첨가하여 김치 제조 시 원료로 동결건조한 원부재료의 사용 가능성을 조사하고 정상 발효 여부 및 김치의 저장성을 연장시킬 수 있는 가능 성을 탐색하기 위해 동결건조한 원부재료를 첨가하여 제조 한 나박김치의 저장 중 품질특성을 분석하였다.

\section{재료 및 방법}

\section{실험재료}

실험에 사용된 배추 및 무, 쪽파, 마늘, 생강은 광주 서부 농수산물도매시장에서 구입하였으며, 고춧가루(Yeongyang farmers, Yeongyang, Kora) 및 동결건조된 마늘분말 및 생강 분말(Sanmaeul, Changnyeong, Korea)은 온라인으로 구매하 였다.

\section{나박김치 제조방법 및 저장 조건}

나박김치 원부재료 중 배추는 손질 후 추대 및 잎부분을 제거하고 세척하여 건조한 다음 $30 \times 30 \mathrm{~mm}$ 로 절단하였으 며, 무와 파는 손질 및 세척 후 $30 \times 30 \times 5 \mathrm{~mm}, 3 \mathrm{~cm}$ 로 각각 절단하였다. 전처리한 무, 배추, 쪽파는 $\mathrm{PE} \mathrm{bag}$ 에 담은 뒤 동결건조기(Operon, FDT-12012, Gimpo, Korea)에 넣어 실 온에서 응축기 온도 $-80^{\circ} \mathrm{C}$, 압력 $10 \mathrm{~mm}$ Torr의 조건하에서 72 시간 동결건조 하였다. 손질한 원부재료 및 동결건조한 원부재료는 Table 1 과 같은 비율로 첨가하여 나박김치를 제조하였으며, 동결건조 된 원부재료의 경우 수율을 측정 한 뒤 생물기준 대비 첨가량을 환산하여 첨가하였다. 이 때 나박김치의 국물을 제조하기 위하여 사용된 고춧가루 국물은 고춧가루 $175 \mathrm{~g}$ 에 물 $23.8 \mathrm{~L}$ 를 가하여 1 시간동안 우려낸 후 $100 \mathrm{mesh}$ 체에 걸러 사용하였다. 제조한 시료는 $500 \mathrm{~g}$ 용량의 PET 용기에 $80 \%$ 충진율인 $400 \mathrm{~g}$ 으로 각각 포장하여 $4^{\circ} \mathrm{C}$ 에서 4 주간 저장시키며 나박김치의 품질변화 를 분석하였다. 제조된 시료의 구분은 Table 2 와 같다.

Table 1. Ingredient ratio of Nabak kimchi

\begin{tabular}{cc}
\hline Material & Ratio (\%) \\
\hline Radish & 16.9 \\
Kimchi cabbage & 10.9 \\
Green onion & 1.4 \\
Garlic & 0.5 \\
Ginger & 0.3 \\
Salt & 1.5 \\
Red pepper powder & 0.5 \\
Water & 68 \\
\hline
\end{tabular}

Table 2. Ingredient composition of Nabak kimchi

\begin{tabular}{cccccc}
\hline \multirow{2}{*}{ Ingredients } & \multicolumn{5}{c}{ Samples } \\
\cline { 2 - 6 } & $\mathrm{A}$ & $\mathrm{B}$ & $\mathrm{C}$ & $\mathrm{D}$ & $\mathrm{E}$ \\
\hline Radish & Raw & Raw & $\mathrm{FD}^{1)}$ & FD & - \\
Kimchi cabbage & Raw & Raw & FD & - & FD \\
Green onion & Raw & FD & FD & FD & FD \\
Garlic & Raw & FD & FD & FD & FD \\
Ginger & Raw & FD & FD & FD & FD \\
\hline
\end{tabular}

${ }^{1)} \mathrm{FD}$, Freeze-dried ingredients.

\section{$\mathrm{pH}$ 및 적정 산도}

$\mathrm{pH}$ 는 나박김치의 건더기와 국물을 blender로 분쇄한 후, pH electrode(ORION 3 STAR, Thermo scientific, Waltham, $\mathrm{MA}, \mathrm{USA}$ )를 직접 넣어 측정하였다. 적정산도는 blender로 간 반죽상태의 시료 약 $1 \mathrm{~g}$ 을 정확히 달아 적당히 희석(100 $\mathrm{mL}$ ) 하여 여과(Advantec No. 1)한 여과액 $20 \mathrm{~mL}$ 에 0.01 
$\mathrm{N} \mathrm{NaOH}$ 용액으로 $\mathrm{pH}$ 가 8.3이 될 때까지 적정하여 소비된 $0.01 \mathrm{~N} \mathrm{NaOH}$ 용액 소비량을 구한 후 다음의 식에 따라 lactic $\operatorname{acid}(\%, \mathrm{w} / \mathrm{v})$ 로 환산하였다.

$$
\text { 적정산도 }(\%, \mathrm{w} / \mathrm{v})=\frac{(A-B) \times 0.0009 \times f \times D}{S} \times 100
$$
$\mathrm{A}$ : 본 시험에 소비된 $0.01 \mathrm{~N} \mathrm{NaOH}$ 용액의 $\mathrm{mL}$ 수
B: 바탕시험에 소비된 $0.01 \mathrm{~N} \mathrm{NaOH}$ 용액의 $\mathrm{mL}$ 수
f: $0.01 \mathrm{~N} \mathrm{NaOH}$ 용액의 역가
$\mathrm{D}$ : 희석배수
$\mathrm{S}:$ 시료채취량 $(\mathrm{g})$

\section{염 도}

염도는 blender로 분쇄한 시료 약 $1 \mathrm{~g}$ 을 정확히 달아 100 배 희석하여 여과한(Advantec No. 1) 여과액을 $10 \mathrm{~mL}$ 를 취하여, $2 \%$ potassium chromate $1 \mathrm{~mL}$ 를 넣어 $0.02 \mathrm{~N} \mathrm{AgNO}_{3}$ 용액으로 적정하여 다음의 식을 이용하여 계산하였다.

$$
\text { 염도 }(\%, \mathrm{w} / \mathrm{v})=\frac{(A-B) \times 0.00117 \times f \times D}{S} \times 100
$$
$\mathrm{A}$ : 본 시험에 소비된 $0.02 \mathrm{~N} \mathrm{AgNO}_{3}$ 용액의 $\mathrm{mL}$ 수
$\mathrm{B}$ : 바탕시험에 소비된 $0.02 \mathrm{~N} \mathrm{AgNO}_{3}$ 용액의 $\mathrm{mL}$ 수
f: $0.02 \mathrm{~N} \mathrm{AgNO}_{3}$ 용액의 역가
$\mathrm{D}$ : 희석배수
$\mathrm{S}:$ 시료채취량 $(\mathrm{g})$

\section{조직감}

조직감은 texture analyzer(Model TAXT-2, Stable Micro Systems, Ltd., London, UK)를 사용하여 약 5 회 반복 측정하 였다. 나박김치의 무와 배추는 동일한 크기를 각각 선별하 여 중심부를 cylinder probe(no. $\mathrm{p} / 2$ )를 사용하여 조직감을 측정하였다. 이 때 texture analyzer의 운영조건은 pretest speed $5.0 \mathrm{~mm} / \mathrm{sec}$, test speed $0.5 \mathrm{~mm} / \mathrm{sec}$, posttest speed 10.0 $\mathrm{mm} / \mathrm{sec}$, rupture test speed $2.0 \mathrm{~mm} / \mathrm{sec}$, distance $15 \mathrm{~mm}$ 로 하였다.

\section{미생물학적 특성}

일반세균의 경우, 일반세균 계수용 film(Aerobic Count plate, 3M Co., St. Paul, MN, USA)을 사용하여 단계별로 희석한 시료를 접종한 후 $30^{\circ} \mathrm{C}$ 에서 48 시간 배양하여 계수하 였다. 총 젖산균의 경우, MRS agar(Lactobacilli MRS agar, Difco Co., Franklin Lakes, NJ, USA)에 BCP(bromocresol purple) 지시약을 $25 \mathrm{ppm}$ 으로 넣어 제조한 배지를 사용하여 단계별로 희석한 시료를 접종한 후 pouring culture method 로 $30^{\circ} \mathrm{C}$ 에서 48 시간 배양하고 yellow 발색 반응을 나타낸 colony(유기산 생산균)를 계수하였다. 효모 및 곰팡이의 경 우, 단계별로 희석한 시료를 효모 및 곰팡이 계수용 film(Yeast and Mold Count plate, 3M Co., St. Paul, MN, $\mathrm{USA}$ )에 접종한 후 $30^{\circ} \mathrm{C}$ 에서 48 시간 배양하여 계수하였다. 대장균 및 대장균군은 시료 $10 \mathrm{~g}$ 을 $180 \mathrm{~mL}$ 의 $0.85 \% \mathrm{NaCl}$ 에 가하여 1 분간 stomaching하여, 대장균 및 대장균군 계수용 film(E. coli/coliform count plate, 3M Co., St. Paul, MN, USA) 에 단계별 희석액 $1 \mathrm{~mL}$ 을 접종한 후 $30^{\circ} \mathrm{C}$ 에서 48 시간 배양 하였다. 대장균군은 생성된 붉은 집락 중 주위에 기포를 형성하고 있는 colony를 계수하였고, 대장균은 생성된 파란 집락 중 주위에 기포를 형성하고 있는 colony를 계수하였 다.

\section{관능검사}

관능검사는 묘사분석 및 차이식별 검사를 통하여 개발한 김치의 관능적 묘사용어를 사용하여 설정된 평가방법을 사용하였으며, 훈련된 김치 관능요원 10 명을 선발하여 김 치의 관능평가를 실시하였다. 관능평가는 제조 직후( 0 일) 를 제외한 모든 저장기간 동안 진행되었으며, 이때 나박김 치 시료는 국물과 건더기 부분을 약 $20 \mathrm{~g}$ 씩 균일하게 혼합 하여 용기에 담아 제공하였다. 관능평가는 9점 척도법에 따라 나박김치의 냄새(잘 익은 냄새, 이취), 맛(잘 익은 맛, 이미), 조직감(아삭한 정도, 무른 정도, 질긴 정도), 전체적 기호도를 평가하였다.

\section{통계분석}

실험결과는 3회 반복 후 평균과 표준편차를 계산하여 표기하였으며, IBM SPSS Statistics(19.0, IBM Co., Armonk, $\mathrm{NY}, \mathrm{USA}$ )를 이용하여 시료별에 따른 결과값에 대해 ANOVA 검정을 실시하여 유의적인 경우 $(\mathrm{p}<0.05)$, Duncan's multiple range test로 사후검정하였다.

\section{결과 및 고찰}

\section{화학적 특성}

동결건조한 원부재료를 이용한 나박김치의 화학적 특성 은 Fig. 1 2에 나타내었다. 나박김치의 염도는 1.59 1.63\% 수준으로 나타났으며 시료에 따른 차이는 나타나지 않았다 (Data not shown).

나박김치의 $\mathrm{pH}$ 는 제조 직후 대조구(A) 및 생원재료와 동결건조한 부재료 처리구(B)에서 5.76 5.77로 나타났으 며, 동결건조 처리구인 C, D 및 E에서는 5.78 7.93으로 나타 나 시료에 따른 유의적인 차이를 보였다 $(\mathrm{p}<0.05)$. 저장기간 이 증가할수록 나박김치의 $\mathrm{pH}$ 는 점차 감소하는 경향을 나 타냈으며, 저장 14 일차에 대조구 및 생원재료와 동결건조 한 부재료 처리구에서 약 $\mathrm{pH} 4.3$ 수준까지 감소하였으나 
동결건조 처리구에서는 $\mathrm{pH} 5.0$ 이상을 유지하며 $\mathrm{pH}$ 의 감소 가 지연되었다. 일반적으로 알려진 물김치의 최적 $\mathrm{pH}$ 범위 는 3.8 4.2 수준으로 보고(22,27)되었으며, 본 연구에서는 대조구 및 생원재료와 동결건조한 부재료 처리구의 경우 저장 14 21일차에 최적 $\mathrm{pH}$ 를 나타내었으며, 동결건조처리 구 $(\mathrm{C}, \mathrm{D}$ 및 $\mathrm{E})$ 의 경우 저장 21 28일차에 최적 $\mathrm{pH}$ 에 도달하 였다. 저장 28 일 후 동결건조한 무 및 부재료 처리구(D)를 제외한 모든 시료는 pH 3.66 3.87 수준으로 감소한 반면 동결건조한 무 및 부재료 처리구는 $\mathrm{pH} 4.06$ 으로 다른 시료 보다 높게 나타났다. $\mathrm{Ku}$ 등(28)은 김치의 발효단계를 $\mathrm{pH}$ 가 숙성 후 5.5 이하로 완만하게 감소되는 초기발효단계와 이 후 급속하게 감소하여 $\mathrm{pH}$ 4.0 4.2에 도달하는 중간발효단 계, $\mathrm{pH} 4$ 이하로 떨어지는 최종발효단계로 구분할 수 있다 고 보고하였는데, 동결건조처리구 중 동결건조한 무 및 부 재료 처리구(D)는 저장 28 일 후에 중간발효단계에 도달함 으로써 다른 시료에 비해 발효가 지연되는 것을 알 수 있었 다.

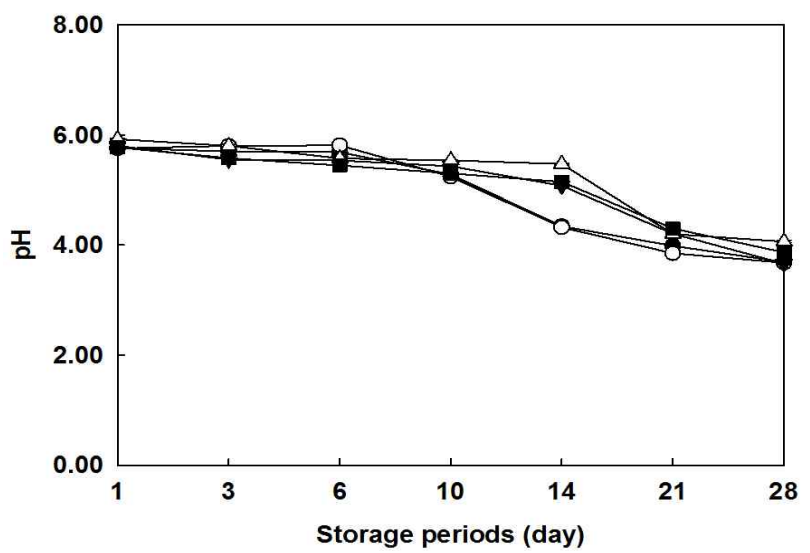

Fig. 1. Changes in $\mathrm{pH}$ of Nabak kimchi with freeze-dried ingredients during storage.

, Control (A); $\bigcirc$, Raw ingredients and freeze-dried minor ingredients (B); Freeze-dried ingredients and minor ingredients $(\mathrm{C}) ; \triangle$, Freeze-dried radish and minor ingredients (D); $\mathbf{\square}$, Freeze-dried cabbage and minor ingredients (E).

김치류의 경우 숙성기간 중 $\mathrm{pH}$ 가 3.0 이하로 감소하지 않은 것으로 보고되었는데 이는 김치류에 존재하는 산이 약산으로 그 해리도가 작기 때문에 $\mathrm{pH}$ 가 3.0 이하로 감소하 지 않은 것으로 알려져 있으며, 특히 물김치의 경우 김칫국 물에 존재하는 유리아미노산의 완충작용에 의해 $\mathrm{pH}$ 의 변 화가 배추김치보다 적은 것으로 보고되어 있다(29,30). 나 박김치의 $\mathrm{pH}$ 가 저장 28 일 후에 $\mathrm{pH} 3.5$ 이하로 감소하지 않은 것은 이에 기인한 것으로 생각되며, 동결건조한 무 및 부재료를 이용하여 나박김치를 제조한 처리구의 경우 다른 시료에 비해 저장기간 전반에 걸쳐 더 높은 $\mathrm{pH}$ 를 유지 하며 유의적 차이를 나타내었다 $(\mathrm{p}<0.05)$.

김치의 적숙기와 달리 과숙기에는 부패세균 및 잡균류가 증가하므로 신맛과 $\mathrm{pH}$ 값이 일치하지 않아 김치의 신맛을
나타내는 직접적인 지표로는 산도가 사용된다(31). 동결건 조한 원부재료를 이용하여 제조한 나박김치의 산도는 제조 직후 0.15 0.16\%로 나타났으며, 저장 10 일차까지 동결건조 한 배추 및 부재료 처리구(E)를 제외한 모든 시료에서 뚜렷 한 차이가 나타나지 않았다(Fig. 2). 동결건조한 배추 및 부재료 처리구(E)에서는 저장 3 일차부터 점차 증가하는 경 향을 나타내어 저장 10 일차에는 $0.20 \%$ 의 산도를 나타내었 다. 저장 14 일차에 나박김치의 산도는 $\mathrm{pH}$ 와 비슷한 경향을 나타내며 모든 시료에서 점차 증가하여 $0.22 \sim 0.32 \%$ 수준으 로 나타났다.

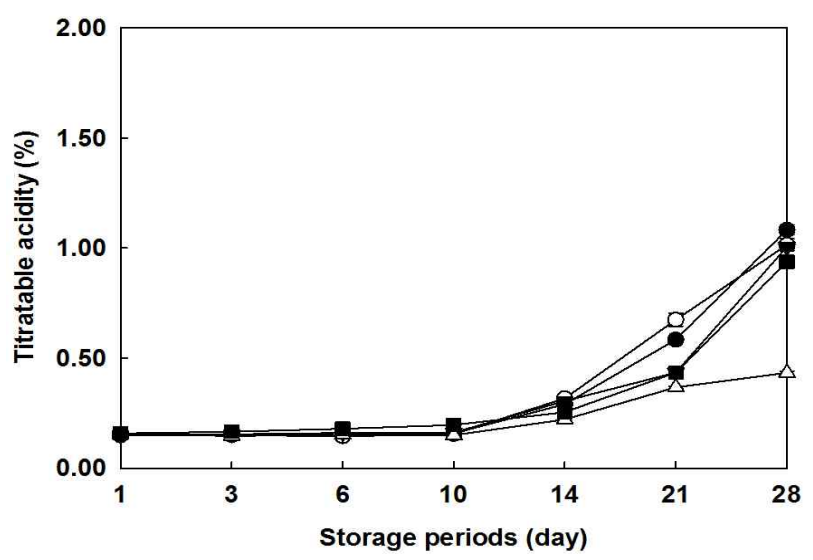

Fig. 2. Changes in titratable acidity of Nabak kimchi with freeze-dried ingredients during storage.

- Control (A); $\bigcirc$, Raw ingredients and freeze-dried minor ingredients (B); $\nabla$ Freeze-dried ingredients and minor ingredients $(\mathrm{C}) ; \triangle$, Freeze-dried radish and minor ingredients (D); $\mathbf{\square}$, Freeze-dried cabbage and minor ingredients (E).

나박김치의 적정산도는 $0.17 \sim 0.31 \%$ 로 보고(27)되었는 데, 본 연구에서는 저장 14 일차에 나박김치가 적정산도에 도달한 것을 알 수 있었다. 저장 21일 이후 대조구 및 생원재 료와 동결건조한 부재료 처리구에서 각각 $0.58,0.67 \%$ 의 산도를 나타낸 반면 동결건조 처리구는 0.37 0.43\%로 나타 나 동결건조에 따른 유의적 차이를 나타내며 발효가 지연되 는 것을 확인할 수 있었다. 일반적으로 김치류 중 물김치의 경우 배추김치의 적숙기 산도인 0.6 1.0\%보다 낮게 나타나 는데 이는 물김치 제조 시 첨가되는 부재료의 양이 적고 다른 김치보다 많은 양의 물이 사용되기 때문에 산도가 낮게 나타나는 것으로 보고되어 있다(32). 본 연구에서는 동결건조한 무 및 부재료 처리구를 제외한 모든 시료에서 $\mathrm{pH}$ 가 4.0 수준으로 가장 많이 감소한 저장 28 일차에 산도도 $1 \%$ 에 가깝게 도달한 것으로 나타났다. 결과적으로 나박김 치의 $\mathrm{pH}$ 및 산도는 대조구에 비해 동결건조 처리구에서 변화가 확연하게 지연되는 것을 확인하였으며, 시료 중 생 원재료 및 동결건조 부재료 처리구(B)는 대조구와 비슷한 발효 패턴을 보이지만 저장 28 일 후에는 대조구에 비해 더 낮은 산도를 나타내었다. 또한 시료 중 동결건조 무 및 부재료 처리구(D)는 $\mathrm{pH}$ 의 감소 및 산도의 증가가 지연되고 
Table 3. Changes in hardness of Nabak kimchi with freeze-dried ingredients during storage

(Unit: kg)

\begin{tabular}{|c|c|c|c|c|c|c|c|c|}
\hline \multirow{2}{*}{\multicolumn{2}{|c|}{ Samples }} & \multicolumn{7}{|c|}{ Storage periods (day) } \\
\hline & & 0 & 3 & 6 & 10 & 14 & 21 & 28 \\
\hline \multirow{5}{*}{ Radish } & Raw & & & & $0.69 \pm 0.07$ & & & \\
\hline & $A^{1)}$ & $0.89 \pm 0.06^{2 \mathrm{bc} B 3)}$ & $0.80 \pm 0.07^{7 \mathrm{C}}$ & $0.83 \pm 0.04^{\mathrm{abC}}$ & $0.86 \pm 0.02^{\mathrm{abC}}$ & $1.00 \pm 0.07^{\mathrm{dB}}$ & $0.96 \pm 0.09^{\mathrm{cdC}}$ & $0.81 \pm 0.07^{7 \mathrm{BC}}$ \\
\hline & B & $0.84 \pm 0.05^{\mathrm{bcB}}$ & $0.87 \pm 0.02^{\mathrm{bcC}}$ & $0.82 \pm 0.05^{\mathrm{bC}}$ & $0.82 \pm 0.03^{\mathrm{bC}}$ & $0.89 \pm 0.04^{\mathrm{cB}}$ & $0.72 \pm 0.06 \mathrm{aB}$ & $0.83 \pm 0.03^{\mathrm{bC}}$ \\
\hline & $\mathrm{C}$ & $0.64 \pm 0.12^{\mathrm{nsA}}$ & $0.63 \pm 0.16^{\mathrm{B}}$ & $0.59 \pm 0.05^{\mathrm{B}}$ & $0.65 \pm 0.07^{\mathrm{B}}$ & $0.59 \pm 0.17^{\mathrm{A}}$ & $0.66 \pm 0.11^{\mathrm{B}}$ & $0.72 \pm 0.14^{\mathrm{B}}$ \\
\hline & D & $0.62 \pm 0.11^{\mathrm{cA}}$ & $0.52 \pm 0.03^{\mathrm{bA}}$ & $0.52 \pm 0.03^{\mathrm{bA}}$ & $0.51 \pm 0.04^{\mathrm{bA}}$ & $0.48 \pm 0.02^{\mathrm{abA}}$ & $0.42 \pm 0.09^{\mathrm{aA}}$ & $0.62 \pm 0.03^{\mathrm{cA}}$ \\
\hline \multirow{5}{*}{ Cabbage } & Raw & & & & $0.62 \pm 0.04$ & & & \\
\hline & $\mathrm{A}$ & $0.53 \pm 0.11^{\mathrm{aA}}$ & $0.67 \pm 0.06^{\mathrm{abB}}$ & $0.66 \pm 0.12^{\mathrm{abAB}}$ & $0.74 \pm 0.06^{\mathrm{bC}}$ & $0.77 \pm 0.07^{\mathrm{bSS}}$ & $1.08 \pm 0.31^{\mathrm{cB}}$ & $1.09 \pm 0.25^{\mathrm{cB}}$ \\
\hline & B & $0.67 \pm 0.10^{\mathrm{aB}}$ & $0.72 \pm 0.12^{a \mathrm{~B}}$ & $0.70 \pm 0.03^{\mathrm{Ba}}$ & $0.73 \pm 0.05^{\mathrm{abC}}$ & $0.77 \pm 0.13^{\mathrm{ab}}$ & $0.90 \pm 0.20^{\mathrm{bcB}}$ & $1.02 \pm 0.21^{\mathrm{bcB}}$ \\
\hline & $\mathrm{C}$ & $0.57 \pm 0.12^{\mathrm{aAB}}$ & $0.58 \pm 0.02^{\mathrm{aA}}$ & $0.60 \pm 0.05^{\mathrm{aA}}$ & $0.61 \pm 0.06^{\mathrm{B}}$ & $0.76 \pm 0.16^{b}$ & $0.66 \pm 0.10^{\mathrm{abA}}$ & $0.65 \pm 0.06^{\mathrm{abA}}$ \\
\hline & E & $0.51 \pm 0.05^{\mathrm{aA}}$ & $0.57 \pm 0.05^{\mathrm{abcA}}$ & $0.62 \pm 0.03^{\mathrm{bcd} A B}$ & $0.54 \pm 0.02^{\mathrm{abA}}$ & $0.67 \pm 0.15^{\mathrm{d}}$ & $0.65 \pm 0.04^{\mathrm{cdA}}$ & $0.55 \pm 0.04^{\mathrm{abA}}$ \\
\hline
\end{tabular}

${ }^{11} \mathrm{~A}$, Control; B, Raw ingredients and freeze-dried minor ingredients; C, Freeze-dried ingredients and minor ingredients; D, Freeze-dried radish and minor ingredients; E, Freeze-dried cabbage and minor ingredients.

${ }^{2)}$ Mean \pm SD.

${ }^{3)}$ Any means in the same row $(\mathrm{a}-\mathrm{g})$ or column $(\mathrm{A}-\mathrm{E})$ followed by different letters are significantly $(\mathrm{p}<0.05)$ different by Duncan's multiple range test.

있는 것으로 확인되었다.

\section{조직감}

동결건조한 원부재료를 이용하여 제조한 나박김치 중 주재료인 무와 배추의 조직감 변화를 측정하여 Table 3에 나타내었다. 나박김치에서 무의 조직감은 제조 직후 $0.62 \sim 0.89 \mathrm{~kg}$ 수준으로 나타났으며, 대조구 및 생원재료와 동결건조한 부재료 처리구의 경우 생무의 $0.69 \mathrm{~kg}$ 보다 더 높은 조직감을 나타내었다. 저장기간 전반에 걸쳐 동결건 조 처리구의 조직감은 생원부재료를 사용한 처리구(A 및 $\mathrm{B})$ 보다 낮게 나타나 대조구(A) 및 생원재료와 동결건조한 부재료 처리구(B)>동결건조한 원부재료 처리구(C)>동결 건조한 무 및 부재료 처리구(D) 순으로 조직감이 낮게 나타 났다. 저장기간에 따른 차이는 뚜렷하게 나타나지 않았으 며, 시료 중 동결건조한 무 및 부재료 처리구(D)는 생무의 조직감보다 전반적으로 낮게 나타났다. 나박김치의 저장 중 초기 조직감의 감소는 삼투압에 의하여 조직액의 용출 및 소금의 침투로 인한 무조직의 변화에 의한 것으로 생각 된다(27).

나박김치 중 배추의 조직감은 무와 비슷한 경향을 나타 내며 대조구 및 생원재료와 동결건조한 부재료 처리구에 비해 동결건조 처리구에서 낮은 값을 나타내었다. 동결건 조 처리구 $(\mathrm{C}$ 및 $\mathrm{E})$ 는 생 배추의 조직감인 $0.62 \mathrm{~kg}$ 보다 저장 전반에 걸쳐 낮게 나타났다. 배추의 조직감은 저장기간이 증가할수록 점차 증가하는 경향을 나타내며 저장 말기인 21 28일차에 가장 높은 값을 나타내었다. 또한 대조구 및 생원재료와 동결건조한 부재료 처리구는 동결건조 처리구 에 비해 저장 21 일 이후에는 뚜렷한 차이를 나타내며 시료
간의 유의적 차이를 보였다 $(\mathrm{p}<0.05)$.

식물성 식품에 존재하는 섬유소는 식물체내에서 결정형 및 비결정형의 혼합체로 존재하는데 이러한 섬유소의 특성 은 식물성 식품의 조직이 과도하게 질겨지거나 부스러짐 없이 그 형태를 유지하는 데 기여하는 것으로 알려져 있다. 그러나 동결 및 건조와 같은 물리적 처리에 의해 섬유소의 결정형과 비결정형의 혼합체가 원래의 평형상태로 복귀하 지 못하면 식물성 식품의 조직이 질겨질 가능성이 있다고 보고되었다(18). 따라서 동결건조한 원재료를 사용한 나박 김치의 조직감은 동결건조 처리에 의해 섬유소의 형태가 기존 형태로 회복되지 못하여 생원부재료를 사용한 나박김 치에 비해 조직감이 저하된 것으로 나타났으나, 동결건조 처리구 중 동결건조 부재료의 첨가는 김치의 조직감에 큰 영향을 미치지 않은 것으로 나타나 김치 제조 시 이용가능 성이 높은 것으로 판단되었다.

\section{미생물학적 특성}

건조식품의 경우 부적절한 환경에서 저장 시 미생물이 생육할 수 있는 가능성이 있으므로 식품의 초기 미생물을 제어하는 것이 식품의 위생안전성 및 저장성을 확보하는데 매우 중요하다(33,34). 동결건조한 원부재료를 이용하여 제 조한 나박김치의 미생물학적 특성은 Fig. 3에 나타내었다. 제조 직후 나박김치의 일반세균은 5.57 6.25 $\log \mathrm{CFU} / \mathrm{g}$ 으 로 검출되었으며, 시료 중 생원부재료를 사용한 대조구(A) 에서 가장 많은 일반세균이 검출되었다. 나박김치는 저장 기간이 증가함에 따라 모든 시료에서 일반세균수가 증가하 는 경향을 나타내었으며, 대조구 및 생원재료와 동결건조 부재료 처리구(B)는 저장 21 일차에 최대 균수가 검출된 
반면 동결건조 처리구(C 및 $\mathrm{E})$ 는 저장 28 일차에 최대 균수 가 확인되었다. 시료 중 생원재료 및 동결건조한 부재료를 사용한 처리구(B)에서는 동결건조한 부재료 첨가로 인해 초기균수가 대조구보다 낮게 검출되었으며, 저장 중에도 대조구에 비해 일반세균이 적게 검출되었다. 또한 동결건 조구의 경우 저장 10 일차까지 대조구 및 생원재료와 동결 건조 처리구에 비해 약 2 3 log 수준이 감소한 5.15 5.57 $\log \mathrm{CFU} / \mathrm{g}$ 으로 검출되었다가 저장 14 일차 이후에는 처리구 에 따라 약간 감소하거나 비슷한 수준으로 검출되었다. 특 히, 동결건조 처리구 중 동결건조한 무 및 부재료 처리구(D) 는 저장 21 일차에 최대균수에 도달하고 저장 28 일차에는 $7.66 \log \mathrm{CFU} / \mathrm{g}$ 이 검출되며 다른 시료와 유의적인 차이를 나타내었다. 이러한 차이는 시료 제조 과정 중 나박김치의 원재료인 무가 형태적으로 배추에 비해 세척 및 손질이 용이하여 미생물의 저감효과가 더 크게 나타나 나박김치의 초기 균수에서 차이를 나타내었으며 결과적으로 저장기간 에 따른 차이도 유지된 것으로 생각된다.

동결건조에 따른 젖산균의 생존율에 영향을 미치는 주요 인자로는 동결건조 전 젓산균의 생육조건, 생육시기(age
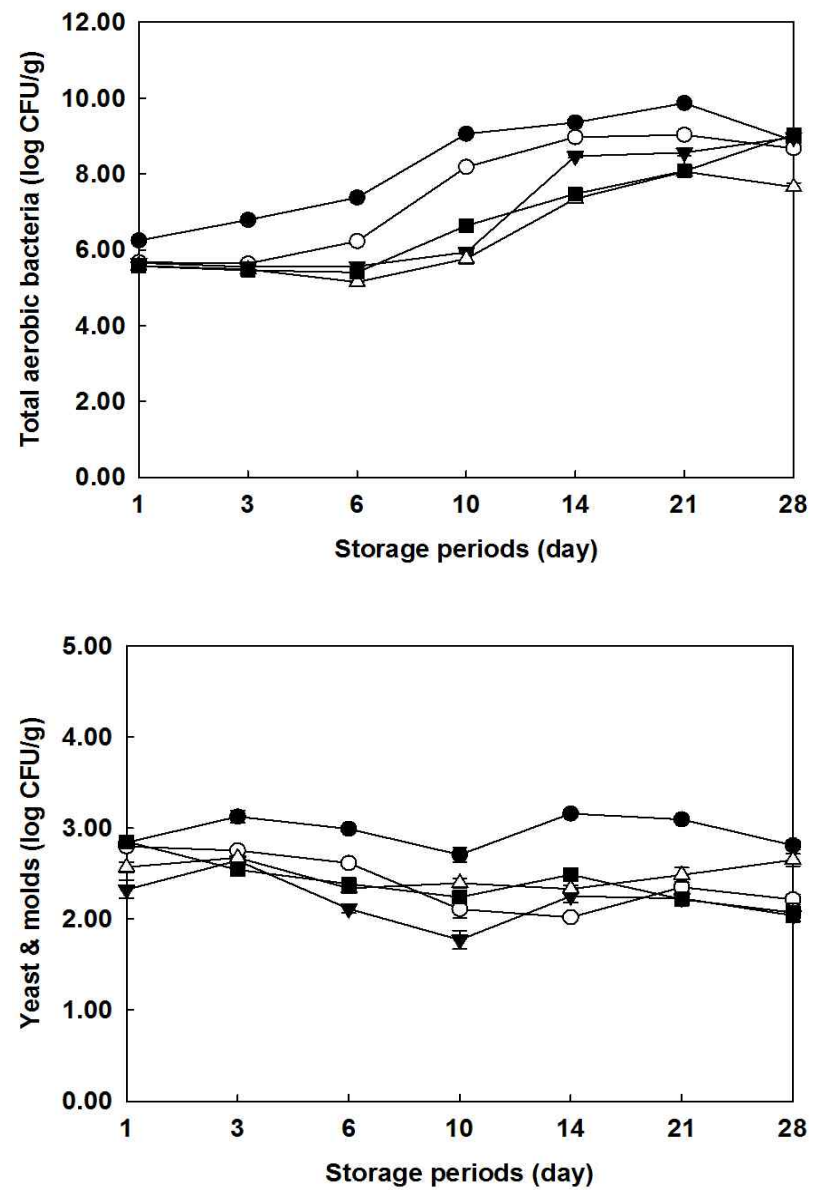

of culture), 동결건조 시료에 함유된 젖산균의 밀도(cell paste loading), 동결건조보호제, 시료 제조방법, 동결건조 후 시료의 복원방법 등이라고 알려져 있다 $(35,36)$. 동결건 조한 원부재료를 이용하여 제조한 나박김치의 젖산균수는 일반세균수와 비슷한 경향을 나타내며 시료에 따른 차이를 나타내었다. 즉, 제조 직후 나박김치의 젖산균수는 대조구 (A), 생원재료와 동결건조한 부재료 처리구(B), 동결건조한 원부재료 처리구(C), 동결건조한 무 및 부재료 처리구(D), 동결건조한 배추 및 부재료 처리구(E)에서 각각 $6.24,5.55$, $5.58,5.51$ 및 $5.52 \log \mathrm{CFU} / \mathrm{g}$ 이 검출되며 대조구에 비해 동결건조 처리구에서 더 적은 균수가 검출되었다. 나박김 치의 저장기간이 증가함에 따라 젖산균수도 증가하여 저장 21 일 및 28 일차에 높은 균수가 검출되었다. 생원재료 및 동결건조한 부재료 처리구에서는 동결건조 처리구와 초기 균수가 비슷한 수준으로 검출되었으나 저장기간이 증가함 에 따라 동결건조 처리구에 비해 더 높은 젖산균수가 검출 되었다. 또한 저장 28 일차에는 생원재료 및 동결건조한 부 재료 처리구는 $8.47 \log \mathrm{CFU} / \mathrm{g}$ 이 검출된 반면, 동결건조 처리구 중 동결건조한 원부재료 처리구(C)와 동결건조한
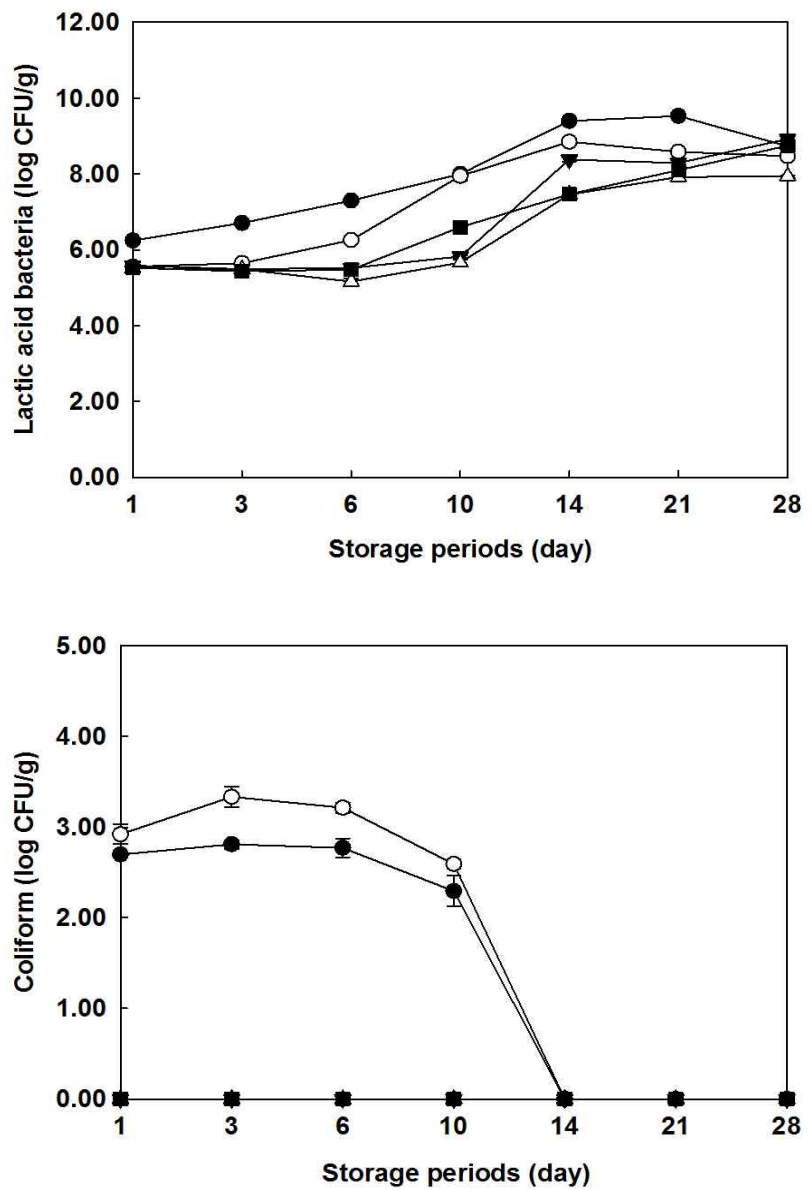

Fig. 3. Changes in the microbial properties of Nabak kimchi with freeze-dried ingredients during storage.

, Control (A); $\bigcirc$, Raw ingredients and freeze-dried minor ingredients (B); $\nabla$, Freeze-dried ingredients and minor ingredients $(\mathrm{C}) ; \triangle$, Freeze-dried radish and minor ingredients (D); $\square$, Freeze-dried cabbage and minor ingredients (E). 
배추 및 부재료 처리구(E)는 $8.92,8.75 \log \mathrm{CFU} / \mathrm{g}$ 이 검출되 었다. 시료 중 생원부재료를 이용하여 제조한 대조구에서 는 저장 전반에 걸쳐 젖산균수가 많이 검출되었으며 동결건 조한 무 및 부재료 처리구(D)는 젖산균수가 적게 검출되었 다. 이는 동결건조에 의해 젖산균의 생육이 저하된 것으로 판단되며 결과적으로 나박김치의 발효를 지연시켜 저장기 간을 연장시킬 수 있을 것으로 생각된다.

Kong 등(22)의 연구에서는 나박김치는 발효초기부터 Leuconostoc 및 Lactobacillus 속과 같은 젖산균수가 높게 검출되었으며 발효온도가 높을수록 빠른 증가속도를 보이 지만, $5^{\circ} \mathrm{C}$ 발효구에서는 발효초기에는 젖산균수가 증가하 지 않고 유지되었다고 보고하였다. 또한 김치는 발효과정 중 김치 재료인 배추나 무에 함유된 발효성 당성분을 이용 하여 젖산균이 산을 생성하는데, 나박김치의 경우 제조 시 다량의 물이 첨가되므로 배추나 무에서 유래되는 발효성 당의 용해를 더욱 용이하게 하는 역할을 하기 때문에 젖산 균수가 높게 검출된다고 보고하였다. 본 연구에서도 나박 김치 제조 후 저온 $\left(4^{\circ} \mathrm{C}\right)$ 에서 발효하였기 때문에 생원료를 사용한 대조구를 제외하고 모든 시료에서 저장 초기 균수의 변화가 적게 나타났으며, 저장기간이 증가할수록 원부재료 에 존재하는 발효성 당 성분이 물에 용해되어 젖산균수가 급격하게 증가한 것으로 보인다.

나박김치의 제조 직후 효모 및 곰팡이 수는 2.33 2.85 $\log \mathrm{CFU} / \mathrm{g}$ 으로 나타났으며 저장 기간 전반에 걸쳐 뚜렷한 차이를 나타내지 않으며 약 2 3 log 수준이 지속적으로 검출되었다. 시료에 따라 동결건조한 원부재료 처리구(C) 에서 저장 기간 동안 다른 시료에 비해 비교적 적은 효모 및 곰팡이수가 검출된 반면 대조구(A)에서는 가장 많은 효모 및 곰팡이수가 검출되어 유의적 차이를 나타내었다. 동결건조 처리구에서는 동결건조한 원부재료 처리구에서 동결건조한 원재료 중 배추나 무를 첨가한 처리구보다 효모 및 곰팡이가 더 적게 검출되었다. 김치에서 발생되는 효모 는 종류에 따라 알코올 생성과 방향 및 풍미를 생성하는 경우도 있으나 막을 형성하고 젖산, 알코올을 산화 분해하 여 젖산에 의해 억제되었던 산패균의 증식을 유발하게 되어 보존성에 악영향을 주는 것으로 알려져 있다 $(5,37)$.

동결건조한 원부재료를 이용하여 제조한 나박김치의 대 장균군은 제조 직후 대조구 및 생원재료와 동결건조한 부재 료 처리구에서 2.70 2.92 log CFU/g 수준으로 검출되었지 만 동결건조 처리구 $(\mathrm{C}, \mathrm{D}$ 및 $\mathrm{E})$ 에서는 저장기간에 전반에 걸쳐 모두 불검출되었다. 대장균군은 저장기간이 증가함에 따라 점차 감소하여 저장 10 일 이후 모든 시료에서 불검출 되었는데, 이는 나박김치가 숙성되어 $\mathrm{pH}$ 감소 및 산도 증가 에 의해 대장균군이 사멸된 것으로 생각된다. 또한 대장균 (E. coli)의 경우, 발효기간 동안 모든 시료에서 검출되지 않았다(data not shown).

\section{관능적 특성}

동결건조한 원부재료를 이용하여 제조한 나박김치의 관 능평가를 실시한 결과는 Table 4와 같다. 관능적 평가 요인 으로는 나박김치의 냄새(잘 익은 냄새, 이취), 맛(잘 익은 맛, 이미), 조직감(아삭한 정도, 질긴 정도) 및 전체적 기호도 이었다. 저장 초반 나박김치의 잘 익은 냄새(ripe odor)는 발효가 진행되지 않아 처리구에 따른 유의적 차이를 나타내 지 않았지만 저장기간이 증가할수록 익은 냄새에서 유의적 인 차이가 나타났다 $(\mathrm{p}<0.05)$. 즉, 저장 14 일 및 28 일차에 동결처리구에 비해 대조구 및 생원재료와 동결건조한 부재 료 처리구(B)에서 높은 점수를 나타내며 생원료 사용 시 나박김치의 숙성이 잘 진행된 것을 알 수 있었으며, 처리구 중 동결건조 배추 및 부재료 처리구 $(\mathrm{E})$ 에서는 패널들에게 가장 낮은 점수를 받은 것으로 평가되었다. 이취도 잘 익은 냄새와 비슷한 경향을 나타내며 저장 10 일차까지 시료간의 유의적 차이를 나타내지 않았으나 저장 14 일차부터 이취가 발생하여 시료 중 대조구에서 이취가 가장 적은 것으로 평가되었다. 또한 저장기간이 증가할수록 이취의 점수도 증가하는 경향을 보였다. 시료에 따라 대조구<생원재료 및 동결건조한 부재료 처리구<동결건조한 원부재료 처리구 <동결건조한 무 및 부재료 처리구<동결건조한 배추 및 부 재료 처리구 순으로 이취의 점수가 높게 나타났다. Ko 등 (38)은 공기 중의 산소에 의한 탈색 반응으로 동결건조된 김치의 색이 연해진다고 보고하였고, 동결건조 후 복원된 시료의 향은 말린 산나물을 물로 복원시켰을 때 나는 냄새 를 띄었다고 보고하였다. 따라서 동결건조한 원부재료를 이용하여 제조한 나박김치에서도 동결건조에 의해 풋냄새 및 산나물 향과 같은 이취가 발생하여 동결건조처리구의 이취가 높게 나타난 것으로 생각된다.

나박김치의 잘 익은 맛(ripe taste)은 저장기간이 증가할 수록 높은 점수를 나타냈으며, 시료에 따른 차이는 뚜렷하 게 나타나지 않았다. 저장 14 일차에만 시료간의 유의성을 나타냈는데 시료 중 생원재료 및 동결건조한 부재료 처리구 에서 가장 높은 점수를 받았으며, 동결건조한 배추 및 부재 료 처리구에서 가장 낮은 점수를 받았다. 이미에서는 저장 초반에는 시료간의 유의적인 차이가 나타나지 않았으나 저장 14 일차부터 동결건조처리구에서 이미가 증가한 것으 로 패널들에게 평가되었다. 저장 28 일 후 시료 중 생원부재 료를 사용한 대조구에서 3.60점으로 가장 낮은 점수를 나타 냈으며, 동결건조 처리구 중 동결건조한 무 또는 배추 및 부재료 처리구(D 및 $\mathrm{E})$ 에서 6.00 6.40으로 가장 높은 점수 를 받았다.

조직감에서 나박김치의 아삭한 정도(firmness)는 생원재 료를 사용한 대조구 및 생원재료와 동결건조한 부재료 처리 구에서 가장 높은 점수를 받았다. 저장기간에 따른 유의적 인 차이를 나타내지 않았으며, 모든 저장기간에 걸쳐 대조 구 및 생원재료와 동결건조한 부재료 처리구는 동결건조 
Table 4. Changes in sensory evaluation of Nabak kimchi with freeze-dried ingredients during storage

\begin{tabular}{|c|c|c|c|c|c|c|c|c|}
\hline \multirow{2}{*}{$\begin{array}{c}\text { Storage } \\
\text { periods (day) }\end{array}$} & \multirow{2}{*}{ Samples ${ }^{1)}$} & \multicolumn{2}{|c|}{ Odor } & \multicolumn{2}{|c|}{ Taste } & \multicolumn{2}{|c|}{ Texture } & \multirow{2}{*}{ Overall acceptability } \\
\hline & & Ripe odor & Off-odor & Ripe taste & Off-taste & Firmness & Toughness & \\
\hline \multirow{5}{*}{3} & A & $4.60 \pm 1.96^{2 \mathrm{~ns} \mathrm{~ns} 3}$ & $3.00 \pm 1.70^{\mathrm{ns}}$ & $3.00 \pm 1.41^{\mathrm{ns}}$ & $3.80 \pm 1.99^{\mathrm{ns}}$ & $6.90 \pm 0.74^{b}$ & $3.10 \pm 1.60^{\mathrm{a}}$ & $5.20 \pm 1.14^{\mathrm{b}}$ \\
\hline & B & $4.30 \pm 1.34$ & $3.50 \pm 1.35$ & $3.50 \pm 2.17$ & $3.20 \pm 1.40$ & $6.40 \pm 1.35^{\mathrm{b}}$ & $3.20 \pm 1.32^{\mathrm{a}}$ & $5.40 \pm 1.84^{b}$ \\
\hline & $\mathrm{C}$ & $4.20 \pm 1.55$ & $3.80 \pm 2.04$ & $3.80 \pm 1.75$ & $4.30 \pm 2.21$ & $2.20 \pm 1.03^{\mathrm{a}}$ & $6.20 \pm 2.15^{\mathrm{b}}$ & $3.10 \pm 1.91^{\mathrm{a}}$ \\
\hline & $\mathrm{D}$ & $3.90 \pm 0.88$ & $3.90 \pm 1.97$ & $3.80 \pm 1.93$ & $4.40 \pm 2.12$ & $2.40 \pm 1.26^{\mathrm{a}}$ & $6.20 \pm 2.10^{\mathrm{b}}$ & $3.10 \pm 1.85^{\mathrm{a}}$ \\
\hline & $\mathrm{E}$ & $3.60 \pm 1.17$ & $4.20 \pm 2.39$ & $3.70 \pm 1.95$ & $4.70 \pm 2.31$ & $2.10 \pm 1.29^{\mathrm{a}}$ & $6.30 \pm 2.50^{\mathrm{b}}$ & $2.60 \pm 1.43^{\mathrm{a}}$ \\
\hline \multirow{5}{*}{6} & A & $4.40 \pm 1.07^{\mathrm{ns}}$ & $3.20 \pm 1.40^{\mathrm{ns}}$ & $3.80 \pm 1.14^{\mathrm{ns}}$ & $2.30 \pm 0.95^{\mathrm{a}}$ & $6.50 \pm 0.97^{b}$ & $3.30 \pm 2.11^{\mathrm{a}}$ & $5.90 \pm 1.20^{b}$ \\
\hline & B & $4.20 \pm 1.14$ & $3.60 \pm 1.96$ & $3.70 \pm 1.06$ & $2.60 \pm 1.07^{\mathrm{a}}$ & $6.40 \pm 0.84^{b}$ & $3.30 \pm 1.89^{\mathrm{a}}$ & $5.20 \pm 1.03^{\mathrm{b}}$ \\
\hline & $\mathrm{C}$ & $3.70 \pm 1.34$ & $4.30 \pm 1.89$ & $4.00 \pm 1.05$ & $3.70 \pm 1.70^{\mathrm{ab}}$ & $1.80 \pm 1.32^{\mathrm{a}}$ & $6.20 \pm 2.10^{\mathrm{b}}$ & $2.60 \pm 0.97^{\mathrm{a}}$ \\
\hline & $\mathrm{D}$ & $4.00 \pm 1.56$ & $4.10 \pm 2.08$ & $3.70 \pm 1.42$ & $3.50 \pm 1.84^{\mathrm{ab}}$ & $2.20 \pm 1.40^{\mathrm{a}}$ & $5.70 \pm 1.83^{\mathrm{b}}$ & $2.80 \pm 1.03^{\mathrm{a}}$ \\
\hline & $\mathrm{E}$ & $3.50 \pm 1.08$ & $4.10 \pm 1.66$ & $4.00 \pm 0.94$ & $4.50 \pm 2.17^{b}$ & $1.80 \pm 1.40^{\mathrm{a}}$ & $6.30 \pm 2.50^{b}$ & $2.30 \pm 0.95^{\mathrm{a}}$ \\
\hline \multirow{5}{*}{10} & A & $5.10 \pm 1.37^{\mathrm{ns}}$ & $2.70 \pm 1.34^{\mathrm{ns}}$ & $4.60 \pm 1.51^{\mathrm{ns}}$ & $3.20 \pm 1.14^{\mathrm{ns}}$ & $6.00 \pm 0.82^{b}$ & $3.40 \pm 1.07^{\mathrm{a}}$ & $5.30 \pm 0.95^{\mathrm{b}}$ \\
\hline & B & $4.50 \pm 1.90$ & $3.10 \pm 0.99$ & $4.30 \pm 1.34$ & $3.20 \pm 1.14$ & $6.70 \pm 0.67^{\mathrm{b}}$ & $3.10 \pm 0.99^{\mathrm{a}}$ & $5.10 \pm 1.10^{b}$ \\
\hline & $\mathrm{C}$ & $4.70 \pm 1.89$ & $3.90 \pm 1.66$ & $4.30 \pm 1.49$ & $4.40 \pm 1.84$ & $2.40 \pm 1.35^{\mathrm{a}}$ & $6.20 \pm 1.99^{b}$ & $2.30 \pm 1.25^{\mathrm{a}}$ \\
\hline & $\mathrm{D}$ & $4.20 \pm 1.75$ & $3.40 \pm 1.65$ & $4.20 \pm 1.48$ & $4.30 \pm 1.83$ & $2.20 \pm 1.14^{\mathrm{a}}$ & $6.60 \pm 1.84^{b}$ & $2.22 \pm 0.83^{\mathrm{a}}$ \\
\hline & E & $4.40 \pm 1.78$ & $4.10 \pm 1.37$ & $4.20 \pm 1.81$ & $4.80 \pm 2.10$ & $2.00 \pm 1.25^{\mathrm{a}}$ & $6.50 \pm 2.32^{\mathrm{b}}$ & $2.00 \pm 1.05^{\mathrm{a}}$ \\
\hline \multirow{5}{*}{14} & A & $6.60 \pm 0.70^{b}$ & $2.20 \pm 0.92^{\mathrm{a}}$ & $6.10 \pm 0.74^{\mathrm{ab}}$ & $2.40 \pm 0.97^{\mathrm{a}}$ & $6.50 \pm 1.27^{b}$ & $3.40 \pm 1.51^{\mathrm{a}}$ & $6.90 \pm 1.10^{b}$ \\
\hline & B & $5.80 \pm 1.14^{\mathrm{b}}$ & $2.70 \pm 1.34^{\mathrm{ab}}$ & $6.20 \pm 1.23^{\mathrm{b}}$ & $2.40 \pm 1.17^{\mathrm{a}}$ & $6.30 \pm 1.34^{\mathrm{b}}$ & $3.20 \pm 1.03^{\mathrm{a}}$ & $6.40 \pm 1.17^{b}$ \\
\hline & $\mathrm{C}$ & $4.50 \pm 1.27^{\mathrm{a}}$ & $3.30 \pm 2.16^{\mathrm{ab}}$ & $5.10 \pm 1.52^{\mathrm{ab}}$ & $3.30 \pm 1.89^{\mathrm{ab}}$ & $2.00 \pm 0.94^{\mathrm{a}}$ & $6.30 \pm 1.95^{\mathrm{b}}$ & $3.00 \pm 1.05^{\mathrm{a}}$ \\
\hline & D & $4.50 \pm 1.72^{\mathrm{a}}$ & $3.40 \pm 1.78^{\mathrm{ab}}$ & $5.20 \pm 1.14^{\mathrm{ab}}$ & $4.10 \pm 2.02^{\mathrm{ab}}$ & $1.60 \pm 0.70^{\mathrm{a}}$ & $6.70 \pm 2.00^{\mathrm{b}}$ & $2.80 \pm 1.32^{\mathrm{a}}$ \\
\hline & E & $4.40 \pm 1.65^{\mathrm{a}}$ & $4.00 \pm 2.36^{b}$ & $4.80 \pm 1.93^{\mathrm{a}}$ & $4.90 \pm 2.47^{\mathrm{b}}$ & $1.30 \pm 0.48^{\mathrm{a}}$ & $7.80 \pm 1.40^{b}$ & $2.10 \pm 1.29^{\mathrm{a}}$ \\
\hline \multirow{5}{*}{21} & A & $6.00 \pm 2.36^{\mathrm{ns}}$ & $1.90 \pm 0.74^{\mathrm{a}}$ & $6.20 \pm 1.93^{\text {ns }}$ & $3.20 \pm 1.62^{\mathrm{a}}$ & $6.10 \pm 1.52^{b}$ & $3.50 \pm 1.84^{\mathrm{a}}$ & $6.50 \pm 1.90^{c}$ \\
\hline & B & $6.40 \pm 1.90$ & $3.20 \pm 1.87^{\mathrm{ab}}$ & $6.70 \pm 1.16$ & $4.20 \pm 2.35^{\mathrm{ab}}$ & $6.10 \pm 1.45^{\mathrm{b}}$ & $4.10 \pm 1.79^{\mathrm{a}}$ & $6.40 \pm 1.26^{c}$ \\
\hline & $\mathrm{C}$ & $5.60 \pm 1.71$ & $4.70 \pm 2.50^{b}$ & $5.90 \pm 1.37$ & $4.50 \pm 2.42^{\mathrm{ab}}$ & $2.50 \pm 1.27^{\mathrm{a}}$ & $6.50 \pm 2.07^{\mathrm{b}}$ & $3.20 \pm 1.69^{b}$ \\
\hline & D & $5.80 \pm 2.25$ & $5.20 \pm 2.35^{b}$ & $5.60 \pm 1.65$ & $6.10 \pm 2.33^{b}$ & $1.70 \pm 1.06^{\mathrm{a}}$ & $6.70 \pm 1.89^{\mathrm{b}}$ & $1.70 \pm 1.25^{\mathrm{a}}$ \\
\hline & E & $5.30 \pm 2.00$ & $5.20 \pm 2.74^{\mathrm{b}}$ & $6.00 \pm 1.49$ & $5.00 \pm 2.21^{\mathrm{ab}}$ & $2.10 \pm 1.29^{\mathrm{a}}$ & $6.90 \pm 1.45^{\mathrm{b}}$ & $2.30 \pm 1.25^{\mathrm{ab}}$ \\
\hline \multirow{5}{*}{28} & A & $6.30 \pm 1.06^{c}$ & $2.30 \pm 1.42^{\mathrm{a}}$ & $6.30 \pm 1.42^{\mathrm{ns}}$ & $3.60 \pm 1.84^{\mathrm{a}}$ & $7.20 \pm 0.92^{b}$ & $3.30 \pm 1.83^{\mathrm{a}}$ & $6.20 \pm 1.69^{b}$ \\
\hline & B & $6.00 \pm 1.25^{\mathrm{bc}}$ & $2.90 \pm 2.02^{\mathrm{ab}}$ & $6.60 \pm 1.35$ & $3.80 \pm 1.87^{\mathrm{ab}}$ & $6.60 \pm 1.26^{b}$ & $3.20 \pm 1.69^{\mathrm{a}}$ & $5.60 \pm 2.01^{\mathrm{b}}$ \\
\hline & $\mathrm{C}$ & $5.20 \pm 1.62^{\mathrm{abc}}$ & $4.60 \pm 2.22^{\mathrm{bc}}$ & $5.5 . \pm 2.27$ & $5.40 \pm 2.17^{\mathrm{bc}}$ & $2.40 \pm 1.58^{\mathrm{a}}$ & $6.10 \pm 2.33^{\mathrm{b}}$ & $3.00 \pm 2.31^{\mathrm{a}}$ \\
\hline & D & $4.60 \pm 1.71^{\mathrm{ab}}$ & $4.80 \pm 2.04^{\mathrm{c}}$ & $4.50 \pm 2.22$ & $6.00 \pm 1.76^{c}$ & $2.00 \pm 0.94^{\mathrm{a}}$ & $5.90 \pm 2.18^{b}$ & $2.40 \pm 1.51^{\mathrm{a}}$ \\
\hline & E & $4.30 \pm 2.00^{\mathrm{a}}$ & $5.60 \pm 2.12^{\mathrm{c}}$ & $5.00 \pm 2.91$ & $6.40 \pm 1.58^{c}$ & $1.80 \pm 0.92^{\mathrm{a}}$ & $5.90 \pm 2.69^{b}$ & $2.10 \pm 1.20^{\mathrm{a}}$ \\
\hline
\end{tabular}

${ }^{11} \mathrm{~A}$, Control; B, Raw ingredients and freeze-dried minor ingredients; C, Freeze-dried ingredients and minor ingredients; D, Freeze-dried radish and minor ingredients; E, Freeze-dried cabbage and minor ingredients.

${ }^{2}$ Mean \pm SD.

${ }^{3)}$ Any means in the same row $(\mathrm{a}-\mathrm{g})$ or column (A-E) followed by different letters are significantly $(\mathrm{p}<0.05)$ different by Duncan's multiple range test.

처리구에 비해 아삭한 정도가 높게 평가되었다. 질긴 정도 (toughness)는 아삭한 정도와 반대되는 경향을 나타내며 생 원재료를 사용한 처리구(A 및 $\mathrm{B})$ 에서 동결건조 처리구(C, $\mathrm{D}$ 및 $\mathrm{E})$ 에 비해 낮은 점수를 얻었다. 따라서 동결건조 처리 구는 동결건조에 의해 나박김치의 주원료로 사용되는 무 및 배추의 조직감이 질겨저 패널들에게 높은 점수를 받아 동결건조에 의해 나박김치의 조직감이 저하된 것을 알 수 있었다.

동결건조한 원부재료를 이용하여 제조한 나박김치의 전
체적 기호도는 냄새 및 맛, 조직감을 고려하였을 때 동결건 조한 처리구에 비해 생원재료를 사용한 대조구 및 생원재료 와 동결건조한 부재료 처리구에서 높게 나타났다. 저장기 간 중 대조구 및 생원재료와 동결건조한 부재료 처리구는 저장 14 일차에 가장 높은 점수를 받았으며, 그 중 대조구의 점수가 더 높아 생원부재료를 첨가한 나박김치를 패널들이 선호한 것을 알 수 있었다. 반면 동결건조 처리구 중 동결건 조한 배추 및 부재료 처리구의 점수가 모든 저장기간에 걸쳐 가장 낮게 나타나 패널들이 동결건조한 배추만 첨가하 
여 나박김치를 제조하였을 때 더 선호하지 않는 것으로 나타났다. Park 등(33)의 연구에서는 동결건조한 김치를 복원한 것과 감마선 조사한 김치의 관능적 품질을 조사하였 을 때 동결건조 후 복원된 김치가 감마선 조사 김치에 비해 더 옅은 색깔을 나타내고, 조직감 저하 및 맛과 향의 강도가 낮아져 전반적인 기호도에서 최저 점수를 나타낸 것으로 보고하였다.

결과적으로 본 연구에서도 동결건조한 원부재료를 이용 하여 제조한 나박김치 중 생원재료 및 동결건조한 부재료 처리구에서 생원부재료를 사용한 대조구와 비슷한 결과를 나타내어 동결건조한 부재료(쪽파, 마늘, 생강)는 나박김치 의 관능적 품질에 영향을 미치지 않는 것을 알 수 있었다. 따라서 이러한 결과를 바탕으로 김치 제조 시 동결건조한 원재료(무, 배추)를 사용할 경우 $\mathrm{pH}$ 및 산도 변화의 지연, 미생물 수의 저감으로 김치의 저장성을 연장시킬 수 있으나 김치의 품질에서 중요 요소인 조직감 및 관능적 품질이 크게 저하되기 때문에 활용 가능성이 낮은 것으로 판단된 다. 그러나 동결건조된 부재료는 김치의 조직감 및 관능적 품질을 저하시키지 않으면서 저장 초기 미생물 수가 감소되 므로 김치의 저장성을 연장할 수 있어 동결건조한 부재료를 이용하여 다양한 김치를 제조할 수 있을 것으로 생각되며, 김치 산업에서 충분한 응용가치가 있을 것으로 판단된다.

\section{요 약}

동결건조된 원부재료(무, 배추, 쪽파, 마늘, 생강)를 이용 하여 나박김치를 제조한 다음 $4^{\circ} \mathrm{C}$ 에서 28 일간 저장하며 이화학적 및 미생물학적 특성과 관능적 특성을 분석하였 다. 나박김치의 제조 직후 $\mathrm{pH}$ 는 5.76 5.93이었으며, 저장기 간이 증가함에 따라 감소하였다. 산도는 저장기간이 경과 할수록 증가하였으며, 저장 28 일차에 동결건조한 무 및 부 재료 처리구(D)의 산도가 $0.43 \%$ 로 나타나 동결건조 원부재 료 처리구 $(\mathrm{C})$, 생 원재료 및 동결건조 부재료 처리구(B)와 유의적인 차이가 확인되었다 $(\mathrm{p}<0.05)$. 배추 및 무의 조직감 은 나박김치의 저장기간 동안 동결건조한 시료에서 대조구 (생원료)에 비해 유의적으로 낮게 나타났으며, 배추의 경우 저장기간이 증가함에 따라 조직감도 점차 증가하는 경향을 나타내었다 $(\mathrm{p}<0.05)$. 나박김치의 제조 직후 일반세균 및 젖 산균수는 생원료로 제조한 대조구에서 약 $1 \log \mathrm{CFU} / \mathrm{g}$ 수준 높게 확인되었으며, 그 차이는 저장 21 일까지 유지되다가 저장 28일차에 동결건조한 무 및 부재료 처리구 $(7 \mathrm{log}$ $\mathrm{CFU} / \mathrm{g}$ )를 제외하고 모든 시료에서 약 $8 \log \mathrm{CFU} / \mathrm{g}$ 수준으로 나타났다. 효모 및 곰팡이수는 저장기간 동안 모든 시료에 서 2 3 $\log \mathrm{CFU} / \mathrm{g}$ 수준을 유지하였으며, 대장균군의 경우 대조구 및 생원재료와 동결건조한 부재료 처리구를 제외한 모든 처리구에서 저장기간 동안 검출되지 않았다. 관능검
사 결과, 생원재료를 사용한 대조구에 비해 동결 건조처리 구에서 전반적으로 낮은 점수를 나타내 동결건조한 주재료 는 나박김치의 관능적 품질이 저하시키지만 부재료(쪽파, 마늘, 생강)는 관능적 품질에 영향을 미치지 않는 것으로 나타나지 않았다. 따라서 동결건조된 부재료의 첨가는 미 생물수가 감소될 뿐만 아니라 김치의 조직감과 관능적 품질 을 저하시키지 않으므로 다양한 김치 제조 시 활용 가능성 이 높으며 더불어 김치의 저장성을 연장하는 효과를 기대할 수 있을 것으로 판단된다.

\section{감사의 글}

본 연구는 세계김치연구소 기관고유사업(KE1503-3)의 연구비 지원을 받아 수행되었으며, 이에 감사드립니다.

\section{References}

1. Cheigh HS, Kim JI (1997) Classification and review of the literatures on kimchi (II). Kimchi Research Institute, 3, 107-121

2. Lim SY, Lee HR, Lee JM (2005) Quality changes of Nabak Kimchi during storage with different levels of fermentation. Korean J Food Culture, 20, 468-475

3. Lee DS, Lee YS (1997) $\mathrm{CO}_{2}$ Production in fermentation of Dongchimi (Pickled Radish Roots, Watery Radish kimchi). J Korean Soc Food Sci Nutr, 26, 1021-1027

4. Kim HR, Park JE, Jang MS (2002) Effect of perilla seed paste on the Yulmoo Mul-kimchi during fermentation. Korean J Soc Food Cookery Sci, 18, 290-299

5. Oh JY, Hahn YS, Kim YJ (1999) Microbiological characteristics of low salt Mul-kimchi. Korean J Food Sci Technol, 31, 502-508

6. Kim GN, Han SB, Kim EJ, Lee DS (2007) Influence of vibration on freezing and fermentation of watery kimchi. J Korean Soc Food Sci Nutr, 36, 1094-1097

7. Lee SE (1999) Investigation of cooking usage of radish cultivars (Raphanus sativus L.) according to the physicochemical and textural characteristics. $\mathrm{Ph} \mathrm{D}$ Thesis, Chungang University, Korea, p 1-153

8. Sohn KH (1991) The sorts and use of kimchi. Korean J Dietary Culture, 6, 503-520

9. Cheigh HS (1995) Critical review on biochemical characteristics of kimchi (Korean fermented vegetable products). J East Asian Soc Dietary Life, 5, 89-101

10. Kim MJ, Chung KJ, Jang MS (2006) Effects of kugija 
(Lycium chinense Miller) extract on the physicochemical properties of Nabak kimchi during fermentation. Korean J Cookery Sci, 22, 832-839

11. Greenfield PF (1974) Cyclic-pressure freeze drying. Chem Eng Sci, 29, 2115-2123

12. Gentzler GL, Schmidt FW (1973) Thermodynamic properties of various water relative to freeze-drying. Trans ASAE, 16, 179-182

13. Jeon EJ, Kim JS (2014) Fermentation characteristics of ice wines prepared with freeze-dried Muscat Bailey A grapes. Korean J Food Sci Technol, 46, 173-179

14. Ko YT, Lee JY (2004) Quality characteristics of kimchi prepared with different part of Chinese cabbage and its quality change by freeze-drying. Korean J Food Sci Technol, 36, 784-789

15. George JP, Datta AK (2002) Development and validation of heat and mass transfer models for freeze-drying of vegetable slices. J Food Eng, 52, 89-93

16. Venir E, Torre MD, Stecchini ML, Maltini E, Nardo PD (2007) Preparation of freeze-dried yogurt as a space food. J Food Eng, 80, 402-407

17. Oh SH, Hwang IG, Kim HY, Hwang CR, Park SM, Hwang Y, Yoo SM, Kim HR, Kim HY, Lee JS, Jeong HS (2011) Quality characteristics by particle size of red pepper powders for pepper paste and kimchi. Korean J Soc Food Sci Nutr, 40, 725-730

18. Ko YT, Kang JH, Kim TE (2001) Quality of freeze-dried kimchi. Korean J Food Sci Technol, 33, 100-106

19. Ko YT, Kang JH (2003) Quality of freeze-dried Yulmoo-kimchi. Korean J Food Sci Technol, 35, 254-259

20. Ko YT, Kang JH (2002) Effects of freeze-drying time on quality of freeze-dried kimchi. Korean J Food Sci Technol, 34, 91-95

21. Ko YT, Kang JH (2002) Changes of volatile odor components in kimchi by freeze-drying. Korean J Food Sci Technol, 34, 559-564

22. Kong CS, Seo JO, Bak SS, Rhee SH, Park KY (2005) Standardization of manufacturing method and lactic acid bacteria growth and $\mathrm{CO}_{2}$ levels of Nabak kimchi at different fermentation temperatures. J Korean Soc Food Sci Nutr, 34, 707-714

23. Lim SY, Lee HR, Lee JM (2005) Quality changes of Nabak kimchi during storage with different levels of fermentation. Korean J Food Culture, 20, 468-475

24. Park LY, Jeong TS, Lee SH (2008) Effects of chaenomelis fructus water extract on the quality characteristics of Mul-kimchi during fermentation.
Korean J Food Preserv, 15, 669-674

25. Kim DC, Won SI, In MJ (2014) Preparation and quality characteristics of Mul-kimchi added with chlorella. J Appl Biol Chem, 57, 23-28

26. Moon SW, Jang MS (2000) Effects of water extract from Omija (Schizandra chinensis Baillon) on Nabak kimchi preservation. J Korean Soc Food Sci Nutr, 29, 814-821

27. Lee SE (2006) Investigation of cooking usage according to the physiochemical and textural characteristics in Nabak kimchi with different radish cultivars. Korean J Culinary Research, 12, 284-298

28. Ku KH, Kang KO, Kim WJ (1988) Some quality changes during fermentation of kimchi. Korean J Food Sci Technol, 20, 476-482

29. Bell TA, Etchells JL (1961) Influence of salt $(\mathrm{NaCl})$ on pectionlytic softening of cucumbers. J Food Sci, 26, 84-90

30. Shin YH, Ann GJ, Kim JE (2004) The changes of hardness and microstructure of Dongchimi according to different kinds of water. Korean J Food Cook Sci, 20, 86-94

31. Park SH, Lee JH (2005) The correlation of physicochemical characteristics of kimchi with sourness and overall acceptability. Korean J Food Cook Sci, 21, 103-109

32. Park IS, Kang SJ, Kim JH, Noh BS (1993) L-lactate oxidase electrode and dissolved oxygen meter for specific determination of $\mathrm{L}(+)$-lactic acid in kimchi during fermentation. Food Sci Biotechnol, 2, 39-43

33. Park JG, Park JN, Han IJ, Song BS, Kim JH, Lee JW, Hwang HJ, Kim YD, Byun MW (2008) Quality comparison between gamma irradiation and freeze drying methods in preparing kimchi for the long-term storage. Korean J Food Preserv, 15, 9-14

34. Kilcast D, Subramaniam P (2000) The stability and shelf-life of food, CRC press, NY, p 63-85

35. Miyamoto-Shinohara Y, Sukenobe J, Imaizumi T, Nakahara T (2008) Survival of freeze dried bacteria. J Gen Appl Microbiol, 54, 9-24

36. To BCS, Etzel MR (1997) Spray drying, freeze drying or freezing of three different lactic acid bacteria species. J Food Sci, 62, 576-585

37. Choi KC (1978) Studies on the yeasts isolated from kimchi. Korean J Microbial, 16, 1-10

38. Ko YT, Kang JH (2001) Effects of ripening on the quality of kimchi or freeze-dried/rehydrated kimchi. Korean J soc Food Cook Sci, 17, 483-489 